\title{
Vavilovian Centers of Plant Diversity: Implications and Impacts
}

\author{
Kim E. Hummer ${ }^{1}$ \\ USDA ARS National Clonal Germplasm Repository, 33447 Peoria Road, Corvallis, OR 97333-2521 \\ Jim F. Hancock \\ Michigan State University, A342C Plant \& Soil Sciences Building, East Lansing, MI 48824-1325
}

Additional index words. center of diversity, center of origin, plant evolution, germplasm, plant breeding, plant exploration

\begin{abstract}
N.I. Vavilov, Academician of the V.I. Lenin All-Union Academy of Agricultural Sciences, takes his place as a founding pillar of knowledge in the cathedral of the origin and development of cultivated plants. Relying on the theories of his revered predecessors, Charles Darwin and Alphonse de Candolle, Vavilov developed the concept of centers of origin for agronomic crops. Vavilov's astute hypotheses set the stage for the modern use of exotic germplasm in plant breeding. Vavilov, a devoted scientist, continued to revise and refine his theory of the centers of origin throughout his lifetime based on additional plant collections and data evaluation. Though he initially proposed three in 1924, and eight in 1935, his final papers of 1940, discussed seven major centers with some minor additions. His concept of specific centers of origin for crop plants was not an isolated aphorism but has directed breeders, on their study and reflection, to the continued improvement and economic development of plants for humanity. Inherent genetic plant variability is the basis of domestication and breeding into crops of economic importance with food, fuel, fiber, and industrial uses. The objective of this article is to present a summary of Vavilov's plant explorations. His collection trips led to the development of his theory of the centers of origin of cultivated crops, the law of homologous variation, as well as his concept of genetic erosion. Further modification of his theories by other scientists and the impact of his ideas are mentioned. His influence on present day conservation of genetic resources are presented.
\end{abstract}

\section{VAVILOV'S THEORIES}

N.I. Vavilov, the brilliant Russian botanist and phytogeographer was a global thinker. Because of his difficult childhood growing up with famine, he focused his efforts and great energy toward improving the human condition. $\mathrm{He}$ wanted to find a way to feed the Russian people (Fowler and Mooney, 1990). From Charles Darwin's ideas, he realized that plant species were not fixed; they evolve over time. Darwin's book, Variation of Animals and Plants Under Domestication (Darwin, 1868) significantly influenced Vavilov's thinking and studies. This book introduced the concept of little particles of inheritance that Darwin termed "pangenes" or what Hugo DeVries shortened to "genes." Vavilov realized that humans in specific locations had been selectively improving crops for millennia. Vavilov thought that Darwin's ideas on evolution constituted the basis for searching for areas where the formation of types originally took place (Dorofeyev and Filatenko, 1992).

Vavilov dedicated his fundamental paper on the Centers of Origin of Cultivated Plants (1926) to Alfonse DeCandolle, another of his well-respected mentors. DeCandolle first posed questions concerning independent centers of origin for plants, but Vavilov took this initial thought to a methodical approach with an inclusive approach

Received for publication 3 Feb. 2015. Accepted for publication 9 Mar. 2015.

This paper was presented as part of a Workshop entitled "Nikolai Ivanovich Vavilov: Plant Genetic Resources Pioneer and Hero" on July 28, 2014 at the ASHS Annual Conference in Orlando, FL.

${ }^{1}$ To whom reprint requests should be addressed; e-mail Kim.Hummer@ars.usda.gov. from plant exploration to development and breeding. He thought of plant breeding as "Эволюиия по воле человека" or "Evolution at the Hand of Man" (Fowler and Mooney, 1990). Vavilov developed his own theories concerning the evolution of wild and cultivated plants (e.g., Vavilov, 1922). These theories were based on his readings and intuition but were extrapolated and confirmed by observations during his collecting expeditions and subsequent plant evaluations made by him and his students.

Three of his significant theories (the law of homologous variation, the centers of origin for cultivated crop plants, and the concept of genetic erosion) have greatly influenced subsequent global plant science, breeding, and conservation efforts. The first is discussed in a separate article (Folta, 2014). The objective of this article is to discuss the other two theories, including their application and impact.

\section{GROUNDWORK: VAVILOV'S EXPLORATIONS}

The sites of ancient agricultural civilizations and of mountainous regions were of particular interest to Vavilov. He and his staff took more than 100 plant expeditions between 1920 and 1940 (Kurlovich et al., 2013) (Table 1; Fig. 1). These expeditions brought back more than 250,000 accessions encompassed more than 10,000 species representatives for the All-Union Institute of Plant Industry.

Vavilov's first agricultural expedition was to Iran in 1916, with many to follow. He collected early landraces of crop plants for testing in northern and droughty areas of Russia, and determined the high-altitude limits of agriculture (Vavilov, 1992, 1997). He also searched for "Persian wheat," reported to be resistant to many diseases (Bazilevskaya and Bakhareva, 1991). He collected many other valuable accessions, including mung bean, chickpea, lentil, everlasting pea, pea, beans, and species of clover, not known at that time in Russia. As a result of this first expedition, 171 grain legumes samples were obtained for the Soviet genebank (Kurlovich et al., 2013).

Next, Vavilov, as the foremost Russian agricultural specialist, was chosen to visit several countries to obtain aid for the ongoing Russian drought. He traveled to the U.K., Sweden, the Netherlands, Canada, and, in 1921, to the United States. Vavilov set up initial cooperation with David Fairchild and his plant explorers at the Bureau of Plant Industry of the U.S. Department of Agriculture.

Vavilov realized that a large treasure of valuable plant genetic resources remained unrevealed to science. In this quest, he visited five continents (Vavilov, 1997), and made his way into almost inaccessible mountain areas, deserts, and forests, risking his life and enduring many hardships. He visited the Middle East, Afghanistan, and Ethiopia for wheat accessions. He traveled to North and South America and the Far East including China, Japan, Korea, and Taiwan. He realized that plant diversity was not distributed equally around the world, but was focused in specific regions. His theoretical concept of the centers of origin for cultivated plants dictated that many trips needed to be taken to obtain the bulk of as species genetic diversity.

Unfortunately, the reality of the Soviet revolution curtailed his grand plans for plant collection and evaluation. Despite political difficulties at home, Vavilov visited almost all of the centers that he had predicted to exist. In the 1940s, when his exit visas were blocked by Soviet officials and he could no longer leave Russia, Vavilov sent his coworkers or students. Even after his death in 
prison (Janick, 2015), his colleagues continued his plans by taking 40 international explorations from 1940 through 1993, to complete the collection and evaluation of plants in the centers of origin predicted by Vavilov.

Table 1. Plant exploration expeditions performed by N. I. Vavilov of the Russian Bureau of Applied Botany, between 1920 and 1940. (Adapted from http://vir.nw.ru/history/history.htm.)

\begin{tabular}{ll}
\hline Yr(s) & \multicolumn{1}{c}{ Country(ies) visited } \\
\hline 1916 & Iran \\
1921 & Canada, United States, Mexico \\
1924 & Afghanistan \\
1925 & Khoresm (Khiva, Novyi Urgench, \\
& Gurlen, and Tashauz) \\
$1926-27$ & Mediterranean countries \\
1929 & China, Taiwan, Japan (Honshu, \\
& Kyushu, and Hokkaido), Korea \\
1930 & United States \\
$1932-33$ & Cuba, Mexico, Ecuador, Peru, Bolivia, \\
& Chile, Brazil, Argentina, Uruguay, \\
& Trinidad, Puerto Rico
\end{tabular}

\section{CENTERS OF ORIGIN FOR CULTIVATED CROPS}

Vavilov's genius began with the concept of plant variability as described by Darwin and others. He took the idea a step further and from "the tip of his pen," realized that our major food crops, which were developed over millennia, must have originated from a central point from which they successfully dispersed. He hypothesized that these "centers of origin" were likely where the genetic diversity of the crop species is highest. Vavilov began to look painstakingly for those centers, through plant exploration and evaluation.

In the introduction of his book, Five Continents, Vavilov compared the approach taken by the U.S. Department of Agriculture and others to that of the Soviet All-Union Institute of Plant Industry concerning the introduction of plants. Vavilov described the American system as an example of "successful eclecticism," the European system as "haphazard," whereas that of Russia was "systematic botanical research which focused on the pools of elementary species formation and the subsequent stages of dispersal of cultivated plants."

Vavilov made sure that his exploration itinerary included visits to more severe mountain areas often close to deserts or semideserts where a great work was previously performed by native agriculturists in the oases. Then the farmers "enhanced" wild species germplasm to produce landraces for his crops of interest.

Initially, Vavilov proposed five centers of origin in 1924, which developed into eight in 1935, although his final papers (1992; 1997 posthumous publications) discussed seven major centers with minor additions. The eight centers of origins (Fig. 2) are as follows:

I. East Asian center includes central and western China, Korea, Japan, and Taiwan. This is the native region for soybeans, millet, many vegetable crops, and fruits. Vavilov estimated that $20 \%$ of the world's cultivated flora originates from eastern Asia.
A

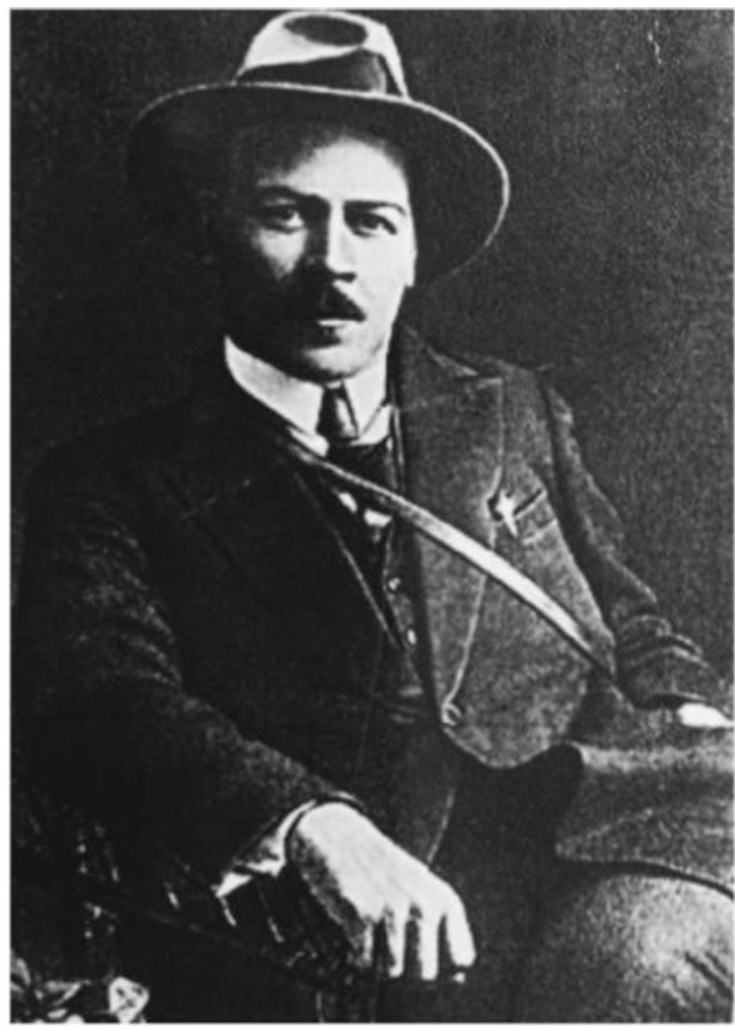

B

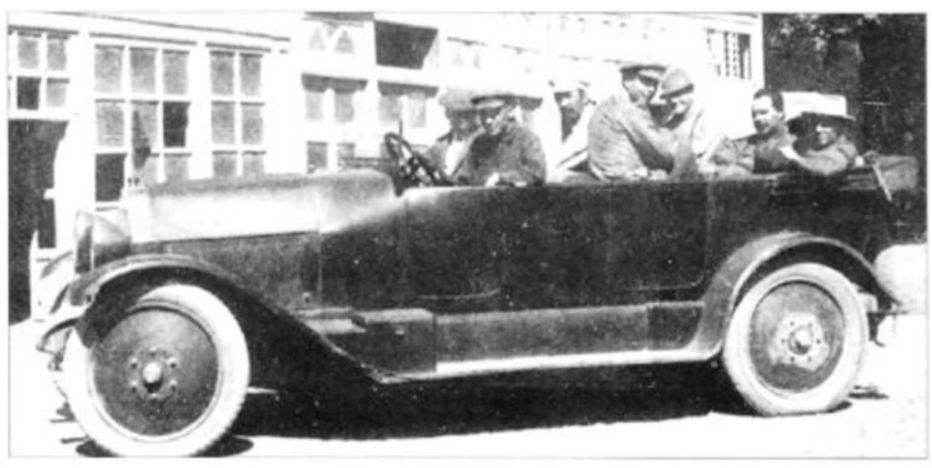

C

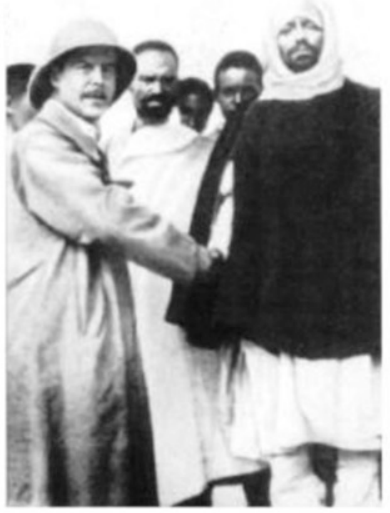

D

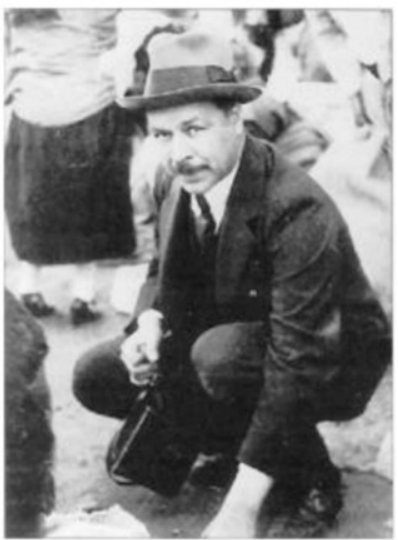

E

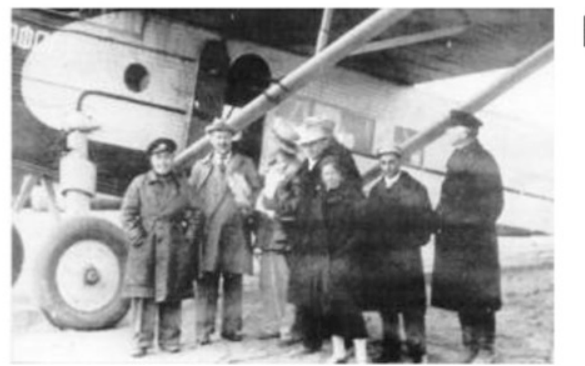

$\mathbf{F}$

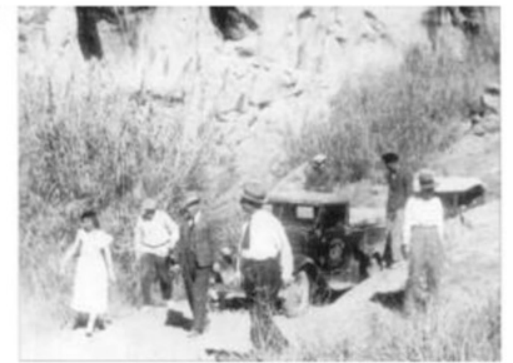

G

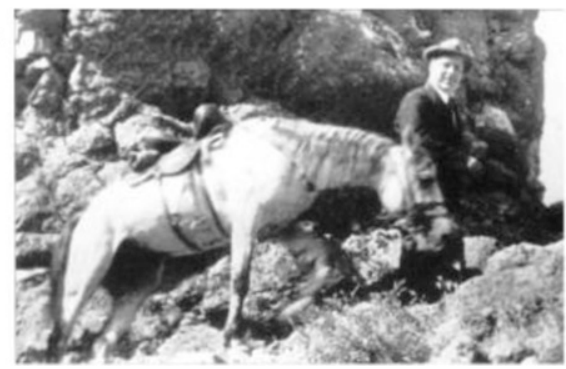

Fig. 1. Expeditions of N.I. Vavilov: (A) portrait before a plant expedition; (B) setting off on first major expedition to Kabul, Afghanistan, 1924; (C) Vavilov shaking hands with Kazazmach, the leader of his plant hunting caravan in Abyssinia 1926-27; (D) collecting seed in a Mexican street market, 1930; (E) near Aral Experiment Station, 1936; (F) expedition to the mountains of Soviet Central Asia, 1936; (G) North Caucuses expedition, 1937. 


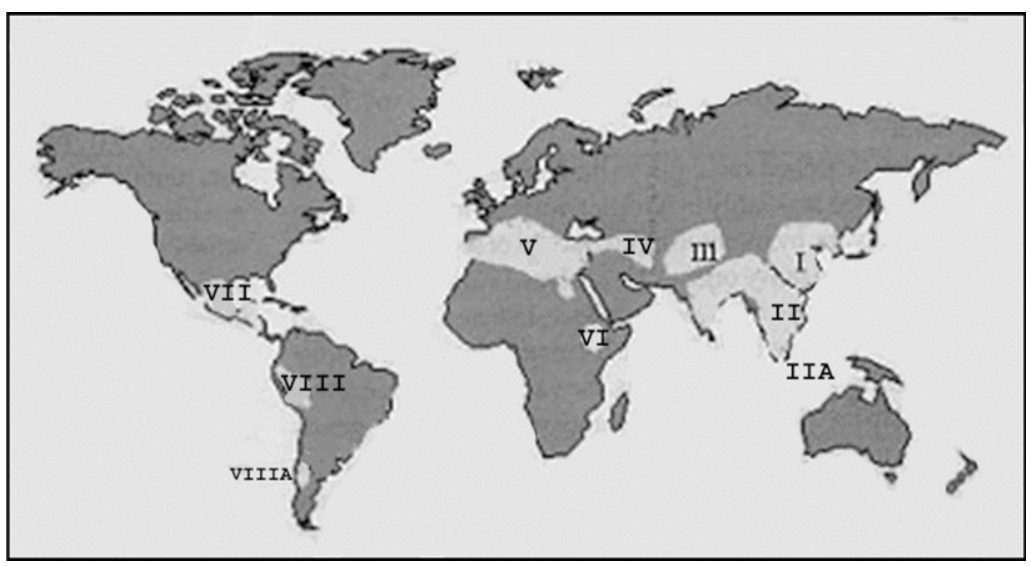

Fig. 2. N.I. Vavilov centers of origin of major world crop plants. Adapted from N.I. Vavilov, 1992.

II. Hindustani center includes tropical India, Indochina, southern China, and the islands of southeastern Asia. This is the native land of rice, sugarcane, tropical fruit, and vegetables. More than $30 \%$ of the world's cultivated plants originate here.

III. Inter-Asiatic center includes the interior mountains of Asia Minor, Iran, Syria, Palestine, Trans-Jordania, Afghanistan, inner Asia, and northwestern India. The native crops include the origin of wheat, rye, and fruit trees. An unbroken line from present day cultivated crops can be traced back to wild forms. About $15 \%$ of the important cultivated plants for the world originated here.

IV. Caucasian center includes original species of temperate fruit trees. Additional species of wheat and rye are also found here.

V. Mediterranean center includes countries bordering on the Mediterranean Sea. Great ancient civilizations selected many vegetable and forage crops including olives and the carob tree. About $10 \%$ of the species of cultivated crops originated here. VI. Abyssinian center produced teff (Eragrostis abyssiniaca Link.), niger seed oil plant (Guizotia abyssiniaca Cass.), a banana [Ensete ventricosum (Welw.) Cheesman], and coffee (Coffea arabica L.). Probably about $4 \%$ of the world crops originated here.

VII. Central American center includes southern North America, Mexico, and the west Indian Islands. Staple plants such as maize, cotton, beans, pumpkins, cocoa, avocados, and subtropical fruits originated here. About $8 \%$ of the important crops of the world originated here.

VIII. Andean center includes the Andean mountain range. This land produced many tuber-bearing crops such as potatoes, quinine tree, and the coca bush.

Vavilov's "centers" accounted for most of the major crops of global economic value of his day. He missed a few significant crops in North America, such as sunflower, and new crops, such as blueberry (Vaccinium corymbosum) and strawberry (Fragaria $\times$ ananassa), have globally developed since his time.

In the tradition of the Bureau of Plant Industry, Vavilov set off on plant collecting expeditions to obtain specific genetic resources that would be of direct use to improve crops, such as wheat and barley, for cultivation in Russia. On his return, the seeds were deposited in locations for use in breeding programs and the remainder for conservation for the long term. He informed his staff not to germinate, grow, or gather plants from these invaluable seeds for their immediate needs. He collected these seeds for breeding use to save these particular plants with desired traits from extinction. He recognized that the seeds he collected from the wild had potential to be lost forever where they had been growing. He saw the imperative need to preserve these plant resources for long-term humanitarian use (Fowler and Mooney, 1990).

His orders were so commanding that though his staff was starving during the siege of Leningrad (now Saint Petersburg) they respected his wishes and did not eat the germplasm. The efforts in Russia in the late 1800 s and early 1900 s, were thus the first in the world to institute long-term ex situ plant conservation in genebanks (Fowler and Mooney, 1990). The Bureau of Plant Industry supported plant collecting expeditions and conservation in Russian genebanks beginning in the $1890 \mathrm{~s}$. In contrast, the U.S. Congress did not establish a genebank system for U.S. germplasm preservation with working collections and a base back-up site at Fort Collins, until after World War II in 1945 (Fowler and Mooney, 1990).

From the beginning of his career, Vavilov recognized the need to conserve genetic resources for humanity. He saw that genetic erosion meant loss of wild diversity and localized landraces. This would be a threat to food security.

Dr. Harry Harlan, colleague of Vavilov, wrote about genetic erosion (Harlan and

\section{GENETIC EROSION OF PLANT GENETIC RESOURCES}

Martini, 1936). His son, Dr. Jack R. Harlan, wrote about the Genetics of Disaster (Harlan, 1972) where he described the terms "genetic vulnerability" and "genetic wipeout." Genetic erosion came strongly into play after the "Green Revolution" began in the 1970s. During this time, new high-yielding cultivars replaced many landraces in the developing countries. These higher yields saved many lives by producing more food, but natural plant diversity was lost in the process. The vision that Vavilov had of conservation of wild types was overpowered by the wave of planting new cultivars.

\section{VAVILOV'S IMPACTS}

N.I. Vavilov has left a lasting impression on international plant genetic resources and conservation. His theories have become incorporated deeply into the core of agricultural dogma taught throughout the world. International policies and plans have been developed based on his ideas. Vavilov's predictions of the occurrence of previously unknown forms and species from specific centers of origin have been a guiding method for biogeographic searches. His concept that diseases and pests coevolved at centers of origin for cultivated crops have provided a roadmap for collectors of valuable genetic diversity.

Alternative views and modifications of Vavilov's centers of origin. Scientists have embraced the Vavilov concept of a center of origin for crop plants, i.e., geographical area where a group of plants were first domesticated. Controversy remains on just where that location is for a particular crop or crop grouping. Scientists recognize that many diverse species can be found at Vavilov's centers and that crop species can have high levels of diversity at multiple locations. The present theories are more comfortable with these points being referred to as a "center of diversity" where a high degree of genetic variation for a particular crop species occurs rather than "centers of origin." Nevertheless, many scientists quibble over the semantics.

Jack R. Harlan, felt strongly that Vavilov "hit the bull's eye" on three "centers of origin," but suggested three additional, larger nonfocused areas called "non-centers" that Harlan said developed independently (Harlan, 1971). Other scientists instead of reducing the number of centers have expanded the number. Recent information from archeology, anthropology, cytology, and linguistics has shed additional information on plant origins. Carbon 14, molecular markers, and other recent techniques are also now available to more precisely identify crop origins. Most of these lie within the boundaries of the developing world (Fowler and Mooney, 1990).

Establishment of global genebanks. One of the lasting impacts of Vavilov's theories is the establishment of international genebanks where genetic resources belong to humanity. Private funding such as that from the Rockefeller and the Ford Foundations was provided 


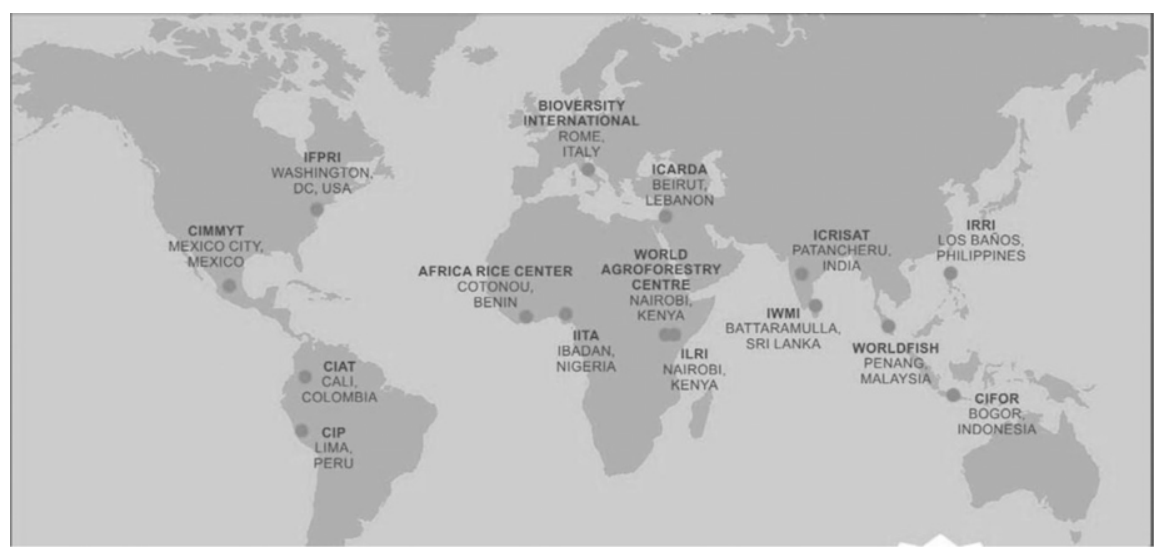

Fig. 3. Locations of the administrative offices for the genebank centers for the Consultitative Group on International Agriculture Research.

to establish centers for research and crop improvement by the Consultative Group (CG) on international agricultural research. The first of these centers was established in Mexico in 1963, the International Maize and Wheat Improvement Center, in Spanish, Centro Internacional de Mejoramiento de Maíz y Trigo (CIMMYT). The second center, the International Rice Research Institute (IRRI), was established in the Philippines. Both were established to bring new highly productive hybrid cultivars to poor locations in developing countries to increase yield and reduce starvation.

Since then, funding became available from the World Bank, through the United Nations Food and Agricultural Organization. Conservation efforts were added to the responsibilities of the centers. At present, 15 CG genebanks (Fig. 3) have been located around the world according to expanded modification of Vavilov's designated centers of origin. The protocols and guiding principles that Vavilov set up for the Russian system have been adopted by the international genebank managers.

In addition, now there is a global "base" genebank, the Svalbard Seed Vault in Norway, where more than 774,000 accessions have been donated from 53 international genebanks representing 156 distinct crop genera (Westengen et al., 2013). These samples will remain at Svalbard for longterm secure storage to protect the food reserves for all humanity.

\section{CONCLUSIONS}

N.I. Vavilov was a brilliant scientist who sacrificed his life for the science of genetics. The theories that he published have become guiding principles for plant breeding as well as for global plant genetic resource conservation. His concept of homologous variation is now applied to molecular genetics and is dogma in plant breeding and evaluation. His guidance for breeders to seek germplasm resistant to pest and diseases at his "centers of origin," now more frequently called "centers of diversity," has been proven to be directly applicable in many crop plants.

Vavilov ideas have transcended his life. They have guided the present genetic resource community where gene banks should be located, and in the proper protocols for genetic resource conservation. His focus on the continued need to conserve genetic resources, and his indomitable conviction for truth, genetics, and the scientific method continues to be an inspiration.

\section{Literature Cited}

Bazilevskaya, N.I. and S.N. Bakhareva. 1991. N.I Vavilov's exploring expeditions and their importance. Bull. Appl. Bot. Genet. Plant Breed. 140:12-23.

Darwin, C. 1868. Variation of animals and plants under domestication. Vol. 1, 2. John Murray, London, U.K.

Dorofeyev, V.F. and A.A. Filatenko. 1992. Preface xix-xxxi. N.I. Vavilov. Origin and geography of cultivated plants. In: V.F. Dorofeyev (ed.), translated by D. Löve. University of Cambridge, Cambridge University Press, Great Britain.

Folta, K. 2014. Molecular mechanisms and the law of homologous variation. HortScience 50:777779.

Fowler, C. and P. Mooney. 1990. Shattering: Food, politics, and the loss of genetic diversity. University of Arizona Press, Tucson, AZ.

Harlan, H. and M.I. Martini. 1936. Problems and results in barley breeding, p. 317. Yearbook of Agriculture. U.S. Department of Agriculture, Washington, D.C

Harlan, J.R. 1971. Agricultural origins: Centers and noncenters. Science 174:468-474.

Harlan, J.R. 1972. Genetics of disaster. J. Environ. Qual. 1:212-215.

Janick, J. 2015. Nikolai Ivanovich Vavilov: Plant geographer, geneticist, martyr of science. HortScience 50:772-776

Kurlovich, B.S., S.I. Repev, M.V. Petrova, T.V. Buravtseva, L.T. Kartuzova, and T.A. Voluzneva. 2013. The significance of Vavilov's scientific expeditions and ideas for development and use of legume genetic resources. PGR Newsletter 124:23-32.

Reznik, S. and Y. Vavilov. 1997. The Russian scientist Nicolay Vavilov, p. 17-29. In: L.E. Rodin (ed.). Five continents. Intl. Plant Genetic Resources Inst., Rome, Italy.

Vavilov, N.I. 1922. The law of homologous series in the case of variation. Saratov (Zakon gomologichesskikh ryadov v nasledstvennoy izmenchivosti, Gubpoligrafotdel, Saratov). J. Genet. 12(12):47-89.

Vavilov, N.I. 1992. Origin and geography of cultivated plants. V.F. Dorofeyev (ed.), translated by D. Löve. Cambridge University Press, Great Britain

Vavilov, N.I. 1997. Five continents. Intl. Plant Genetic Resources Inst., Rome, Italy.

Vavilov, N.I. 2014. Institute of plant industry. History. 8 Jan. 2014. <http://vir.nw.ru/history/ history.htm>.

Westengen, O.T., S. Jeppson, and L. Guarino. 2013. Global ex-situ crop diversity conservation and the svalbard global seed ault: Assessing the current status. PLoS One 8(5): E64146. 